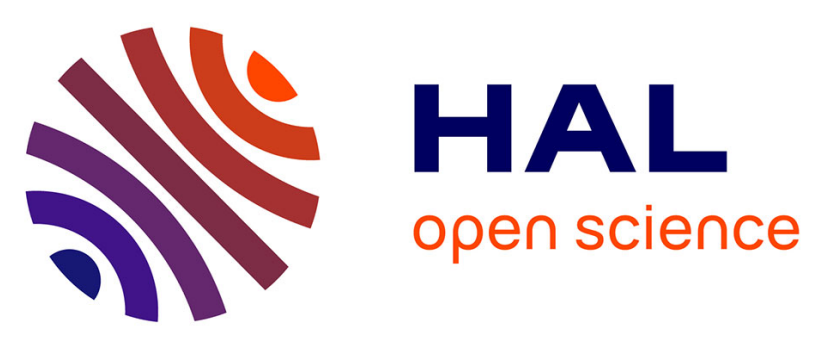

\title{
Defining radiotherapy target volumes using 18F-fluoro-deoxy-glucose positron emission tomography/computed tomography: still a Pandora's box?: in regard to Devic et al. (Int $\mathrm{J}$ Radiat Oncol Biol Phys 2010). \\ Mathieu Hatt, Dimitris Visvikis
}

\section{To cite this version:}

Mathieu Hatt, Dimitris Visvikis. Defining radiotherapy target volumes using 18F-fluoro-deoxy-glucose positron emission tomography/computed tomography: still a Pandora's box?: in regard to Devic et al. (Int J Radiat Oncol Biol Phys 2010).. International Journal of Radiation Oncology, Biology, Physics, 2010, 78 (5), pp.1605. 10.1016/j.ijrobp.2010.08.002 . inserm-00574276

\section{HAL Id: inserm-00574276 https://www.hal.inserm.fr/inserm-00574276}

Submitted on 22 Jul 2011

HAL is a multi-disciplinary open access archive for the deposit and dissemination of scientific research documents, whether they are published or not. The documents may come from teaching and research institutions in France or abroad, or from public or private research centers.
L'archive ouverte pluridisciplinaire HAL, est destinée au dépôt et à la diffusion de documents scientifiques de niveau recherche, publiés ou non, émanant des établissements d'enseignement et de recherche français ou étrangers, des laboratoires publics ou privés. 


\section{DEFINING RADIOTHERAPY TARGET VOLUMES USING 18F-}

FLUORO-DEOXY-GLUCOSE POSITRON EMISSION TOMOGRAPHY /

COMPUTED TOMOGRAPHY: STILL A PANDORA'S BOX?: In Regard

to DEVIC et al (Int J Radiation Oncology Biol Phys 2010

doi:10.1016/j.ijrobp.2010.02.015)

Mathieu Hatt, $\mathrm{PhD}^{*}$

Dimitris Visvikis, $\mathrm{PhD}$

*Corresponding author: Mathieu HATT, PhD

INSERM U650, National Institute of Health and Medical Research,

Laboratoire de Traitement de l'Information Medicale (LaTIM)

CHU Morvan,5 avenue Foch, 29609 Brest, France

Tel: +33(0)2980181 11, Fax: +33(0)298018124,e-mail: hatt@univ-brest.fr

To the Editor: Devic et al. (1) investigated the use of fixed thresholds to define NSCLC tumors PET volumes exhibiting heterogeneous uptake. They found no correlation between the CT-based and the PET-based volumes, and associated the observed variations with intrinsic properties of PET acquisition rather than their segmentation choice. They also concluded that PET-based volumes should not be used for radiotherapy dose painting/boosting. Several studies recently dealt with similar issues $(2,3)$ by considering fixed threshold to determine tumor metabolic 
volumes, demonstrating variability in the threshold values. Other recent studies demonstrated the limitations of fixed threshold and proposed more accurate and robust methods, from adaptive thresholding (4,5) to advanced algorithms (6-8) capable in some cases of handling heterogeneous uptake frequently characterizing tumors treated with radiotherapy.

Fixed thresholds cannot reliably define functional volumes due to their deterministic and binary nature whereas tumor uptake is variable, spatially heterogeneous and dependent on a large number of acquisition and reconstruction parameters. We agree that additional studies are needed to better characterize the correlation between tracer uptake and underlying metabolism. However, irrespectively of such correlation, differentiation of a PET volume from its background is an image segmentation issue that cannot be rigorously addressed using threshold-based methodologies. Those lead to inconsistent tumor volumes in most of the realistic clinical cases (1-5), especially heterogeneous ones $(1,5,8)$. In these cases and in the absence of appropriate segmentation tools, it may be more accurate (although less reproducible) to rely on manual delineation rather than fixed threshold.

The use of inappropriate segmentation tools will lead to misleading conclusions regarding the potential of FDG PET in guiding radiotherapy treatment planning or as a prognostic and predictive factor for therapy response (9). As new algorithms become available and the clinical research applications demonstrate their potential, the medical equipment and software industry should implement them. Societies should develop minimum standards and guidelines regarding functional volumes segmentation, first in clinical research and eventually in clinical practice. This is a slow process and misleading conclusions as a result of the use of inappropriate approaches will reduce the interest of the technique, slowing even further the process of making available new technology. We therefore suggest a more radical stance with avoiding the use of 
any fixed threshold based definition of PET metabolic tumor volumes in the future, especially if they are to be used for any PET image guided therapy application.

\section{References}

1. S. Devic, N. Tomic, S. Faria, et al, "Defining Radiotherapy Target Volumes Using 18F-Fluoro-Deoxy-Glucose Positron Emission Tomography/Computed Tomography: Still a Pandora's Box?" Int J Radiat Oncol Biol Phys 2010; in press corrected proof.

2. D. Han, J. Yu, Y. Yu, et al, "Comparison of 18F-Fluorothymidine and 18F-Fluorodeoxyglucose PET/CT in Delineating Gross Tumor Volume by Optimal Threshold in Patients With Squamous Cell Carcinoma of Thoracic Esophagus", Int J Radiat Oncol Biol Phys 2010;76(4):1235-1241.

3. K. Wu, Y. C. Ung, J. Hornby, et al, "PET CT Thresholds for Radiotherapy Target Definition in Non-Small-Cell Lung Cancer: How Close Are We to the Pathologic Findings?” Int J Radiat Oncol Biol Phys 2010;77(3):699-706.

4. J-F. Daisne, M. Sibomana, A. Bol, et al, Tri-dimensional automatic segmentation of PET volumes based on measured source-to-background ratios: influence of reconstruction algorithms, Radioth. Oncol., 2003;69:247-250.

5. U. Nestle, S. Kremp, A. Schaefer-Schuler, et al, "Comparison of Different Methods for Delineation of 18F-FDG PET-Positive Tissue for Target Volume Definition in Radiotherapy of Patients with Non-Small Cell Lung Cancer", J. Nucl. Med., 2005;46(8):1342-8.

6. X. Geets, J. A. Lee, A. Bol, et al, “A gradient-based method for segmenting FDG-PET images: methodology and validation”, Eur J Nucl Med Mol Im 2007;34:1427-1438.

7. D. W. G. Montgomery, A. Amira, and H. Zaidi, "Fully automated segmentation of oncological PET volumes using a combined multiscale and statistical model", Medical Physics, 2007;34(2):722-736. 
8. M. Hatt, C. Cheze le Rest, P. Descourt, et al, "Accurate automatic delineation of heterogeneous functional volumes in positron emission tomography for oncology applications", Int J Radiat Oncol Biol Phys 2010;77(1):301308.

9. G. Lucignani, "SUV and segmentation: pressing challenges in tumor assessment and treatment", Eur. J. Nucl. Med. Mol. Im., 2009;36:715-720. 